\title{
Study on Early Recognition of Loess Landslides Based on Field Investigation
}

\author{
Dalei Peng, Qiang Xu*, Xing Qi, Xuanmei Fan, Xiujun Dong, Shu Li, Yuanzhen Ju \\ State Key Laboratory of Geohazard Prevention and Geoenvironment Protection, Chengdu University of \\ Technology, Chengdu 610059, Sichuan, China
}

\begin{abstract}
For the purpose of agriculture irrigation, river water has been introduced into Heifangtai region from the Yellow River several times a year since 1968, which ensued a steady rise in underground water level by a yearly rate of $0.18 \mathrm{~m}$ with a cumulative total rise of up to $20 \mathrm{~m}$ over Heifangtai catchment. This ponding effect of water injection triggered landslides (3 5 events per year) at the edge of Heifangtai tableland. Failures of loess slopes have caused high causalities, and inhibited the local economy. This study aims at investigating the distribution patterns of loess landslides and their formation conditions in Heifangtai region, so as to establish approaches to early recognition and prediction of underlying landslides. Landslides in Heifangtai were delineated through visual interpretation of high resolution images obtained by unmanned aerial vehicle photogrammetry. Digital Elevation Model with high resolution $10 \mathrm{~cm}$ was acquired by 3D laser scanning technology and closerange photogrammetry. With field investigation, landslide distribution patterns and characteristics, as well as the local geological structure, were examined and two early recognition criteria for landslides are established. The results indicate that an intact slope section between two old landslide sections is the most possible locations for new landslides and areas with rising groundwater level are prone to landslides. For example, in 2015 a landslide occurred at the gaps of a 2014 landslide body. The rising of local groundwater level was induced either by blockage of underground water outlets by landslide deposits and freeze in winter or by heavy rainfall. Early recognition of loess landslides would protect local communities and land resources from landslide hazards.
\end{abstract}

Keywords: loess landslide, early recognition, landslide potential, rising underground water level, static liquefaction, field investigation

\section{Introduction}

Loess covers about $10 \%$ of the Earth's land surface. It is mainly concentrated in the northern hemisphere temperate zones, semi-arid zones, and the leading edges of deserts (Derbyshire et al 1998, Derbyshire et al 1991, Liu 1985, Pecsi 1990). Many large-scale loess landslides occurred in these areas were reported (Derbyshire and Mellors 1988, Sun 1988, Ishihara et al 1990, Rogers et al 1994, Jefferson et al 2003). The Chinese Loess Plateau with $317,000 \mathrm{~km}^{2}$ constitutes is the largest bulk accumulation of loess on earth (Liu 1985). The Loess Plateau is mainly distributed in four provinces, Shanxi, Shaanxi, Gansu and Ningxia. Loess thickness generally exceeds $100 \mathrm{~m}$ over large areas in the Loess Plateau. The maximum thickness is up to $500 \mathrm{~m}$, measured at a site near Jingyuan County in eastern Gansu (Liu 1985). Catastrophic mass movements with loess origin are recurrent over loess deposit areas (Derbyshire 2001), posing a serious threat to public safety, infrastructures and farmlands (Lin and Liang 1982, Sun 1988,

*Corresponding Author: Xu Qiang, email: xuqiang_68@126.com, Tel: +86 (28) 84073371 
Derbyshire et al 1991).

Existing researches about loess landslides are mainly focusing on the following aspects:

(1) Triggering factors, such as earthquake (Zhang and Wang 2007, Chen et al 2014), extreme precipitation ( $\mathrm{Tu}$ et al 2009, Peng et al 2015), agricultural irrigation (Zhang et al 2009, $\mathrm{Xu}$ et al 2014), reservoir infiltration (Zhang et al 2012b), engineering excavation (Wang et al 2014, Zhuang and Peng 2014) and other engineering activities; (2) Loess landslide mechanisms, such as unsaturated soil mechanics (Muñozcastelblanco et al 2012, Wen and He 2012), soilwater interactions (Zhang et al 2013), infiltration process in loess (Zhou et al 2014) and loess dynamic patterns (Zhang et al 2011); (3) Risk management and control (Zhang and Liu 2010, Zhang et al 2011); (4) Early warning and forecasting.

Most researches on loess landslide ensued from natural catastrophic events. However, pioneer studies on the risk of loess landslide didn't combine the geological circumstances and landslide deformation. Therefore, it is necessary to develop a scientific approach for disaster prevention and risk reduction in close connection with the technology of early recognition of loess landslide.

The success of geohazard prevention and risk mitigation in loess regions in northwestern China relies on early recognition of loess landslide and will contribute to future landslide control. Most past works on early identification of landslide were carried out from the following aspects, such as geological landform (Derbyshire et al 1995, Zhang et al 2012a), mathematical statistics (Gao et al 2010), remote sensing of geographic information technology (Meng et al 2009, Xiong et al 2014), differential Interferometric synthetic aperture radar (Wasowski and Bovenga 2014, Zeng et al 2014), etc. However, there was little loess landslide research about early recognition based on filed investigation (Mentes et al 2009, Xu et al 2012a, Wasowski and Bovenga 2014).

A typical landslide-affected loess region in Heifangtai tableland was chosen as a research basement for early recognition of loess landslide. In recent decades, hydrogeological conditions in Heifangtai basin has been subjected to human activities to a great extent. In 1968, the Yellow River Water Diversion Project was launched for large-area agricultural irrigation. From the same year, Heifangtai started evolving into a populated resettlement because of the construction of dams and hydro-electric power stations of Liujiaxia and Yanguoxia on the Yellow River (Zhou et al 2013). Agricultural production is a major economic source for local community. The irrigation area in Heifangtai is about $7.6 \mathrm{~km}^{2}$. Due to durative agricultural irrigation, the thickness of unsaturated loess layer is greater than $20 \mathrm{~m}$ in natural condition at the edge of the tableland and more than $30 \mathrm{~m}$ in its center. Monitoring result of underwater table in loess layer at the northern margin of Heifangtai confirms that groundwater level has increased by average $0.18 \mathrm{~m}$ per year, cumulatively a total of $20 \mathrm{~m}$ (Xu et al 2014). There were 3 5 loess landslides occurred at the edge of the tableland every year (Fig. 6) (Derbyshire et al 1998, Xu et al. 2009, Zhang and Liu 2010, Wu et al 2014). Recently, the Jiaojia\#4 landslide happened on January 29, 2015, whose volume was about $6 \times 10^{3} \mathrm{~m}^{3}$ and the irrigation channel was ruined in this landslide (Fig. 6a). The Chenjia\#3 landslide occurred on February 26, 2015 , with a volume about $0.3 \times 10^{4} \mathrm{~m}^{3}$, imperiled a high-speed railway nearby (Fig. 6b). Shortly later, the Chenjia\#8 landslide occurred on March 28, 2015 at 11 am (Fig. 6c) and its volume was $5 \times 10^{3} \mathrm{~m}^{3}$, leading to suspension of the China mobile communication optical cable.

The Dangchuan\#2 landslide took place on April 29, 2015 at $7 \mathrm{am}, 5 \times 10^{4} \mathrm{~m}^{3}$ in volume, exhibiting a sliding track from the fourth terrace of the Yellow River to the second terrace. Nevertheless, 3 hours later it was followed by a larger mudstone landslide, $3.5 \times 10^{5} \mathrm{~m}^{3}$ in volume, 780 meters long and 100 meters wide, and the largest thickness of the mudstone deposit was 17 meters. The Dangchuan\#2 landslide is regarded as one of the most catastrophic landslides in the Heifangtai tableland. Therefore, Heifangtai tableland is also known as a "natural laboratory" for loess landslide research.

This study aims to investigate the distribution patterns of loess landslides and its formation conditions in Heifangtai region, so as to establish approaches to early recognition and prediction of 
landslide potentials. The landslides in Heifangtai is delineated by using visual interpretation method based on high resolution images obtained by unmanned aerial vehicle photogrammetry. Digital Elevation Model with high resolution 10 $\mathrm{cm}$ was acquired by the 3D laser scanning technology (Fig. 1) and close-range photogrammetry. With field investigation, researches were performed on the distribution pattern of landslides and its characteristics as well as the local geological structure (Fig. 2). Two early recognition criteria for landslides are established.

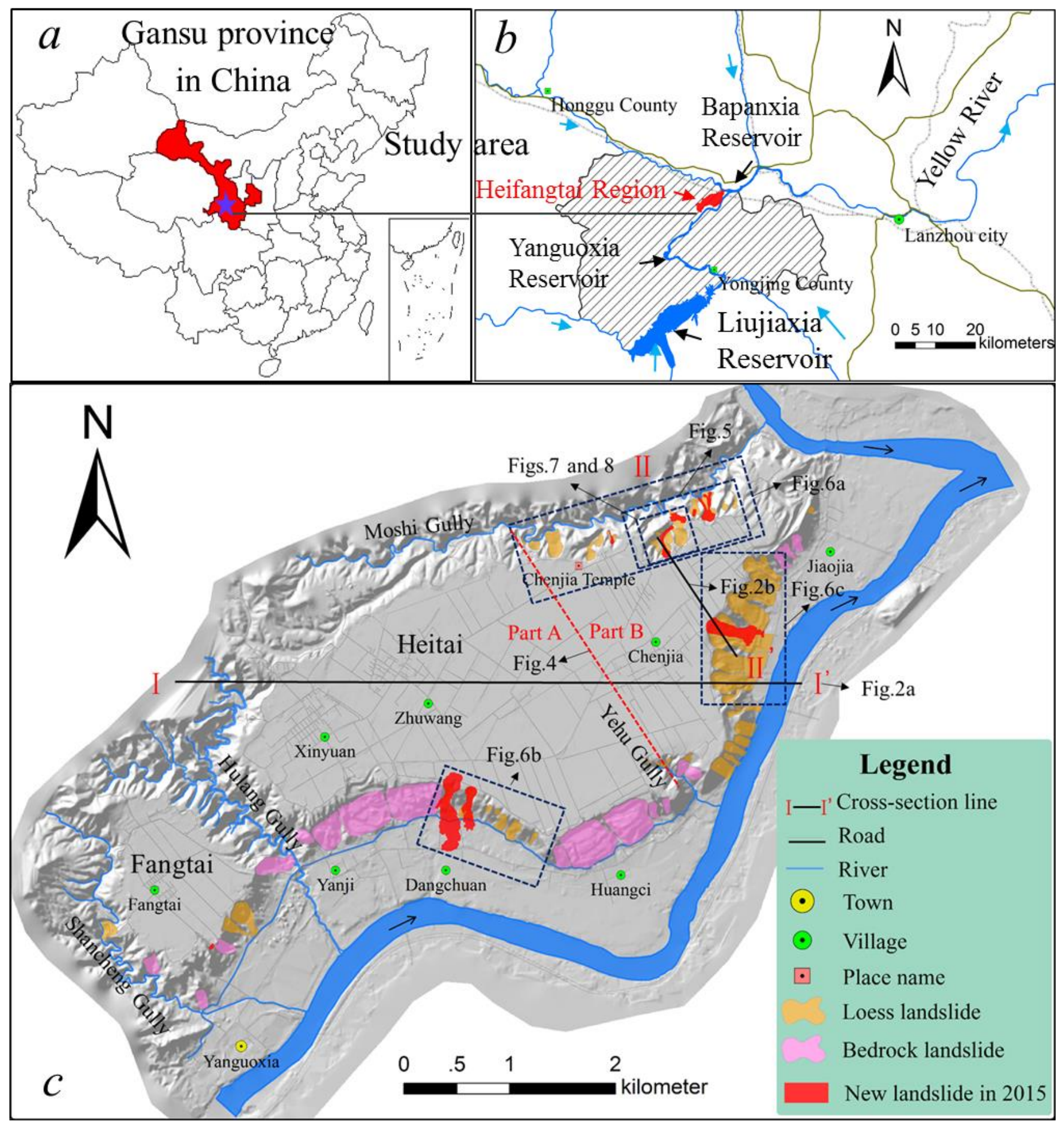

Fig. 1 The loess landslides induced by agricultural irrigation in Heifangtai, Gansu Province, China. a and b show the location of Heifangtai loess tableland. c shows topography and distribution of landslides in Heifangtai region 


\section{Geology and Setting}

\subsection{Location of study site}

Heifangtai tableland is located near the Six Gorge Reservoir, northern bank of the Yellow River in Yongjing County, Gansu Province, China (Figs. 1 $\mathrm{a}$ and $\mathrm{b}$ ). It covers a total area of $13.7 \mathrm{~km}^{2}$, with $7.7 \mathrm{~km}$ in west-east direction, and $2.5 \mathrm{~km}$ in north-south direction. Subjected to active uplift of the Tibetan Plateau, strong neotectonic movements dominate Heifangtai. Precipitous topography and multistage terrace landscape characterize local landform as a result of strong erosive action of the Yellow River. Heifangtai tableland lies on the fourth-level terrace of the Yellow River. There are more than 50 gullies developed in Heifangtai and these trenches are not only a runoff collection, but also drainage courses.

Among them, the Hulang Gully, Moshi Gully and Shancheng Gully developed on Heifangtai tableland, cutting deeply into the pre-Pleistocene (Cretaceous) bedrocks, and created a landform with discrepancy at an elevation of $130 \mathrm{~m}$ with slopes inclined at an angle of $50^{\circ} \sim 60^{\circ}$, making Heifangtai tableland relatively an enclosed hydrological system. Heifangtai tableland consists of Heitai and Fangtai separated by narrow Hulang Gully, the longest gully in Heifangtai (Fig. 1c). Because of the striking similarities between the two terraces (Heitai and Fangtai) in geological properties and geomorphological features, they are regarded wholly as "Heifangtai" tableland (Derbyshire et al 2000). Heitai is located at the confluence of the Yellow River and Huangshui River, an area about $9 \mathrm{~km}^{2}$, and larger than Fangtai $\left(1.5 \mathrm{~km}^{2}\right)$, which is southwest to Heitai (Derbyshire et al 1995) (Fig. 1c). This study focuses on Heitai region (Fig. 4).

\subsection{Formation lithology}

The lithological profile of Heifangtai tableland comprises 4 layers (Figs. 2a and b), from earth surface to bedrock including: (1) Holocene series landslide mass. It is made of post-slide loess, gravel and sand-shale. Crushed soil clutter deposited at slope toe. (2) Upper Pleistocene Loess. It is a mantle of Malan loess. Its thickness is 30 to $50 \mathrm{~m}$. The loess is largely composed of silt with high porosity and weak cementation. Sub-vertical joints are well developed, allowable for phreatic water seepage through contacts. The open-packed fabric structure of loess makes it susceptible to wetting. (3) Upper Pleistocene Mild Clay and Gravel. It comprises two portions. The upper portion is Pleistocene Mild Clay. It is orange silty clay in horizontal layers. The thickness of Mild Clay at the NW side is thicker than that at SE side, with thickness of 3 to $20 \mathrm{~m}$. The lower layer is gravel, formed as a result of weathering and erosion of rocks, with thickness of 1 to $10 \mathrm{~m}$. The composition of gravel mainly includes quartz rock and granite. (4) Lower Cretaceous Mudstone/Sandstone. The bedrock in Heifangtai is constructed with mudstone and sandstone. The thickness of exposed rock stratum at the edge of the plateau is more than $70 \mathrm{~m}$ with attitude of approximately $135^{\circ} \angle 11^{\circ}$ (Fig. 2a).

\subsection{Agriculture irrigation}

Since the early 1960s, several hydropower stations, such as Liujiaxia, Yanguoxia and Bapanxia, have been put forward to construction and Heifangtai was selected as the resettlement for residents in the reservoir areas. Agricultural production becomes a major economic backbone for the local. Since 1968, the Yellow River Water Diversion Project was launched for agricultural irrigation. The irrigated land in Heifangtai is about $7.6 \mathrm{~km}^{2}$. From July 1966 to June 1969, it took three years to successively build three high water conservancy irrigation projects. Since then, more than seven massive irrigation operations in Heifangtai tableland are conducted every year, including once in November for soil moisture conservation, once in April for crops production, two times or more for seeding purpose, and another three times or more for crops growth. According to a report (Geological Environmental Monitoring Institute of Gansu Province, 2001), the annual water irrigation amount was $7.22 \times 10^{6}$ $\mathrm{m}^{3}$ in $1980 \mathrm{~s}$ and $5.76 \times 10^{6} \mathrm{~m}^{3}$ in 1990s. The volume of the pumped water increased to $6.27 \times 10^{6} \mathrm{~m}^{3}$ in 2014. Fig. 3 presents the variation of diverted water from 1981 to 2014. In recent years, some agricultural crops with higher 

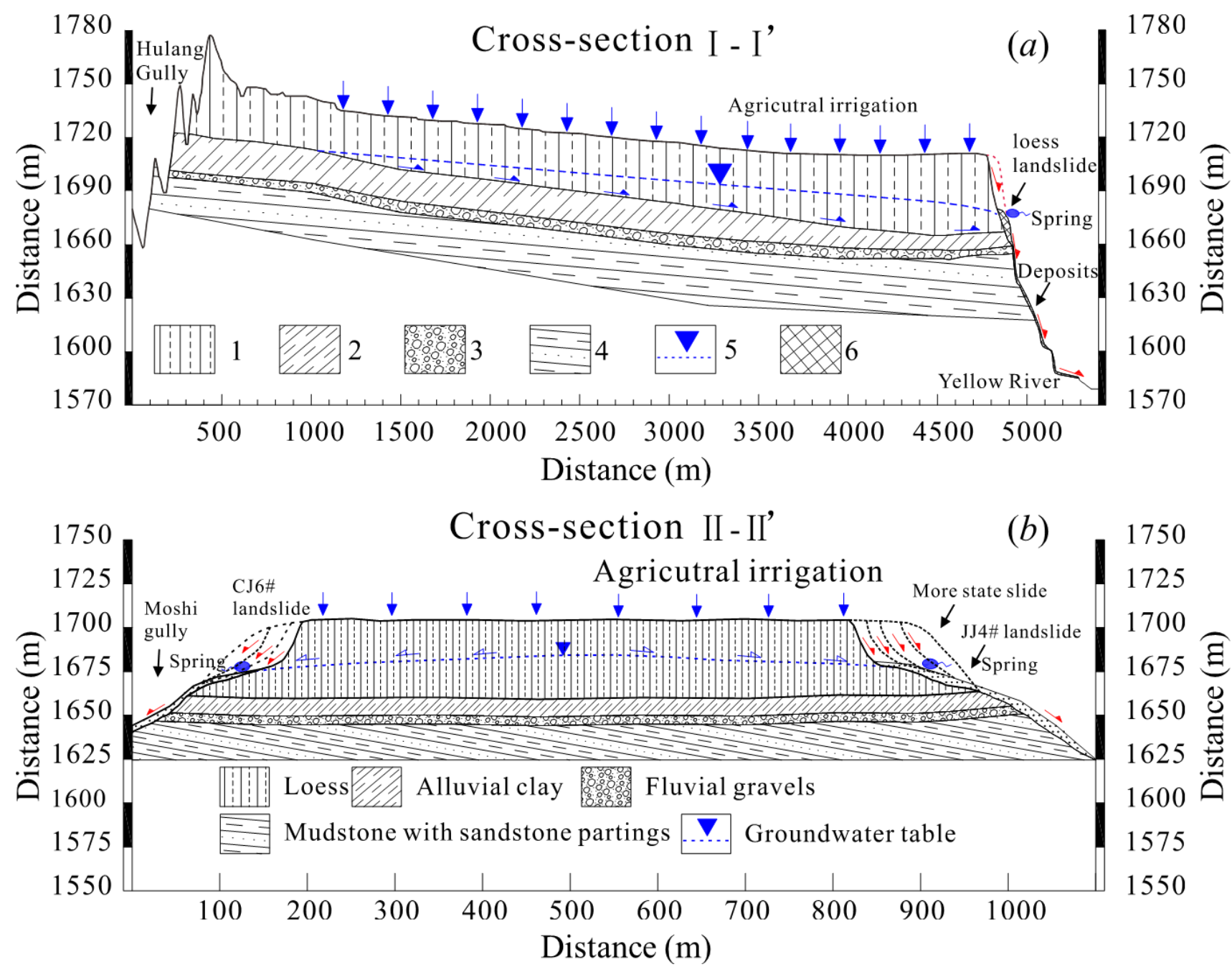

Fig. 2 Cross-section of Heitai tableland and landslide recurrence. a) The typical cross-section; b) Loess landslides in stepback (its location is shown in Fig. 1c)

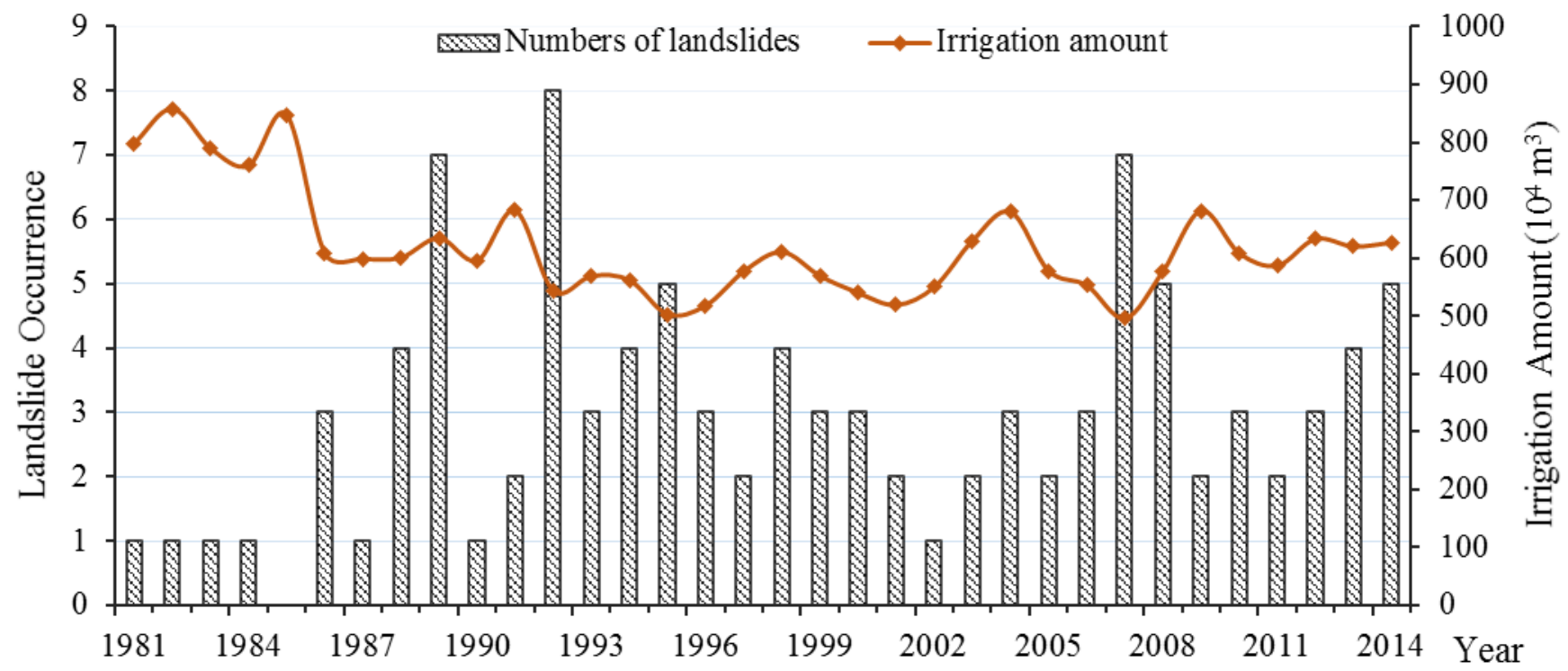

Fig. 3 The relationship between irrigation volumes and landslide occurrences from 1981 to 2014 at Heitai platform 


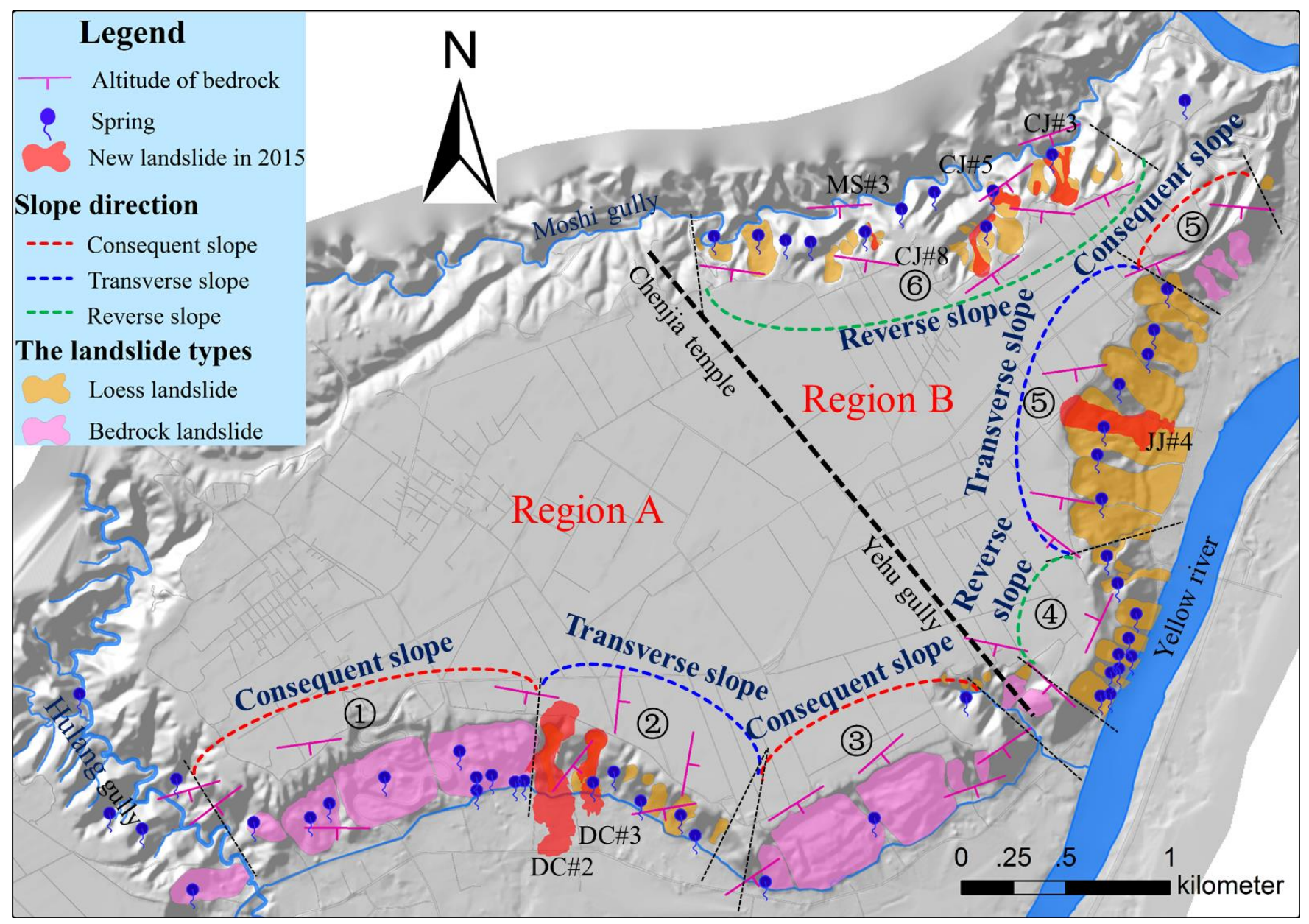

Fig. 4 Regions A and B: six landslide sub-sections at Heitai tableland in Fig. 1c

economy values (such as strawberry and fruit trees) have been introduced into this area, but they consume more soil moisture for growth than traditional crops. The volume of lifting-water into Heifangtai keeps a high level from 2007 to 2014, which substantially modified the local geohydrological environment and inevitably changed geohazard pattern.

\subsection{Spatial distribution of loess landslide}

The landslides caused by irrigation in Heitai tableland can be categorized into two subgroups: loess landslides and loess bedrock landslides. A total of 68 landslides have been identified in Heitai tableland, among them, seven were within the Yehu Gully, and the rest 61 on the edge of the tableland. Those landslides are distributed by groups and overlap with each other. Spatially, the tableland can be divided into region $\mathrm{A}$ and $\mathrm{B}$ by
Yehu Gully and Chenjia Temple. Landslides in Region A are mainly loess bedrock landslides with relatively larger volume varying from $1 \times 10^{5}$ to $6 \times 10^{6} \mathrm{~m}^{3}$; while landslides in Region $\mathrm{B}$ are mainly loess landslides with smaller volume varying from $4.9 \times 10^{3} \mathrm{~m}^{3}$ to $2.2 \times 10^{6} \mathrm{~m}^{3}$. The Region $\mathrm{A}$ and the region $\mathrm{B}$ can be further divided into 6 sections, (1) Xinyuan, (2) Dangchuan, (3) Huangci, (4)Jiaojiaya, (5)Jiaojia and (6)Moshigou (Fig. 4). In consideration of geological structure, bedrock altitude and groundwater outlet locations, formation conditions of landslides at Heitai were examined in regions as shown in Fig. 2a. Sections (1) and (3) in Region A are bedrock landslides distributed along the dipping direction of the bedrock $\left(160^{\circ} \angle 10^{\circ}\right)$. The groundwater also exposed bedrock at its outlets. As observed, large-scale bedrock slides are inclined to occur in this region. The dipping direction of bedrock 
illustrated in section (2) is almost perpendicular to the slope direction, which decreases the occurrence probability of bedrock slides in this region. There were few loess landslides found in this section before the irrigation operation. This was due to a lower groundwater level in the west of Heifangtai as opposed to an increase of underground water level in recent years, which caused landslides in this section. The rising groundwater level resulted in saturation of loess basis, namely "soft basis". It was the major cause of loess landslides developed in the Region B, representatively at Sections (5) and (6). Landslides at Section (4) present plastic flow-like deformation features due to both the soft basis and man-made slope-cutting. (3) Groundwater level rising is the main triggering factor of landslide. Hence large loess bedrock landslides are mostly located on consequent slopes while loess landslides are located on transverse slopes and reverse slopes (Fig. 4).

\section{Early Recognition Method for Loess Landslide}

A latent landslide in loess is defined as a slope which is inclined to creep or has disclosed evidence of deformation but has not yet motivated, which is in natural balance state. However, once it suffered from certain natural triggers and engineering activities, a latent landslide is quite likely to immediately burst into landslide disaster. Besides, loess landslides have occurred on a smaller scale in this area. It is believed that large-scale loess landslide disasters probably could be recurrently triggered by human activities in the future. Landslide prediction and deformation observation is essential to landslide disaster prevention and mitigation.

\subsection{The gaps prone for new landslides occurrence}

The gaps between the landslide sections where no landslide happened before, are the most likely locations for new landslide occurrence.

As early as 1899, a general classification of landform was proposed by geomorphologist W.M. Davis from the United States (Davis 1899). He believed that all the varied forms of lands were dependent upon, or, as the mathematician would say, were functions of three variables, structure, process and time (Davis 1899).

The section (5), Jiaojia section was quite often selected by researchers due to its scale, occurrence frequency and catastrophe. GIS was utilized to inquire landslide documentation, analysis and temporal forecasting (Meng et al 2009). Comparisons were made by landslides boundary and their height from 1970 to 2013. The pattern of slope deformation process was quite distinct before and after the time of landslide occurrence (Meng et al. 2009) when compared with the landslides in the surrounding area.

In Section (6), Moshi Gully, there began to occur loess landslide at northern Heitai since 1990s. The landslide occurrences increased from (1) in 2002 to (13) in June 2015 (Fig. 5). During the period of the two landslide events, (1) in 1998 and (2) in 2003 (Xu et al 2009), there was no sliding until November 2004 (Fig. 5b). While the (6) occurred in November 2012 (Fig. 5c). Although the occurrence of landslide is relatively independent, but there is a certain regularity in the space. With landslides occurring in surrounding areas, the gaps (where no landslides happened) are highly likely to have loess landslide in following months or year according to the landslide boundary change in section (5) and section (6).

Following the research of Davis (1899), changes in deformation process and boundary for landslide were addressed by Meng (2009) and according to the principle of "equal width of the same conditions for the development of landslides", many potential landslides were identified at the end of December 2014 and they are further evaluated for the risk of landslide in the next period of time (Figs. 6 a, b and c).

It was found that 4 new landslides occurred in the first half of 2015 and another 9 landslides by October 2015 (Figs. 4, 6 d, e, f and g), which is consistent with the landslide risk zoning which was completed in December 2014 (Figs. 6 a, b and c). 

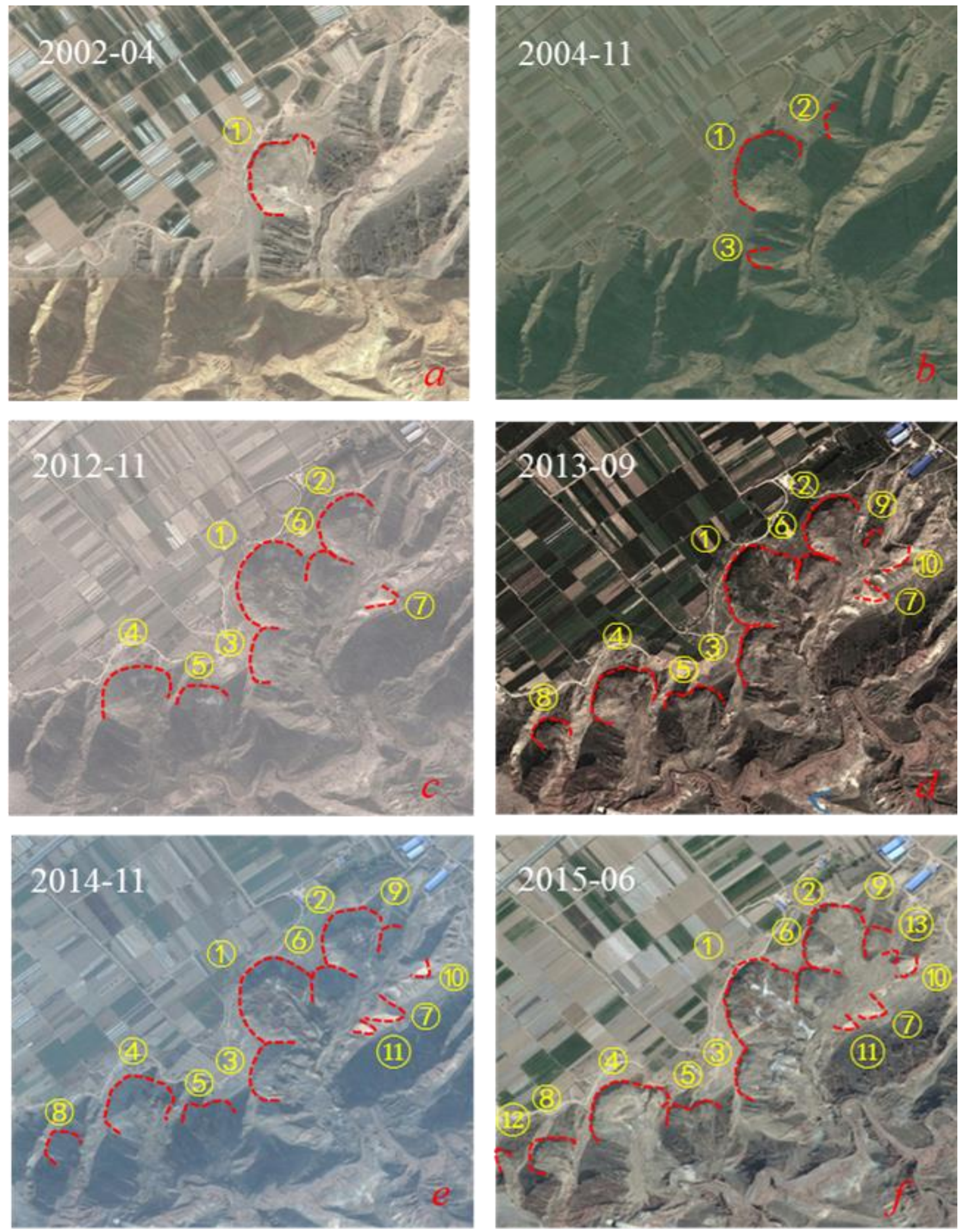

Fig. 5 Loess landslides with progressive recession (images from Google) (for location, see Fig. 1c) 


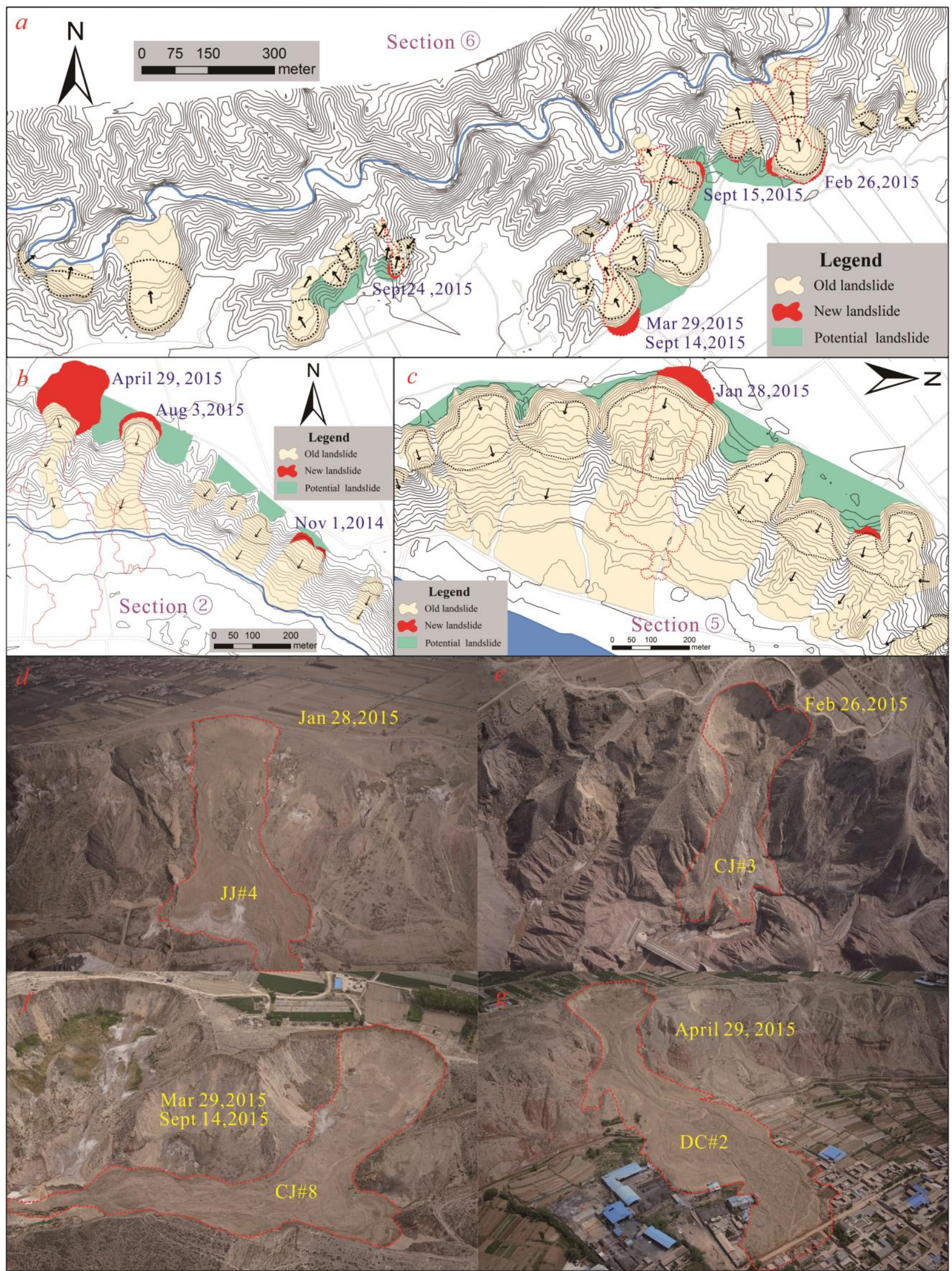

Fig. 6 Potential landslides delineated in December 2014 for risk assessment at Heifangtai platform (for location, see Fig. 1c). In Figs. a, b and c, the three sections (section (6), section (2) and section (5)) are marked for potential loess landslides in 2014, as well as landslide in 2015. Figs. d, e, f and g demonstrated the typical loess landslides in 2015 


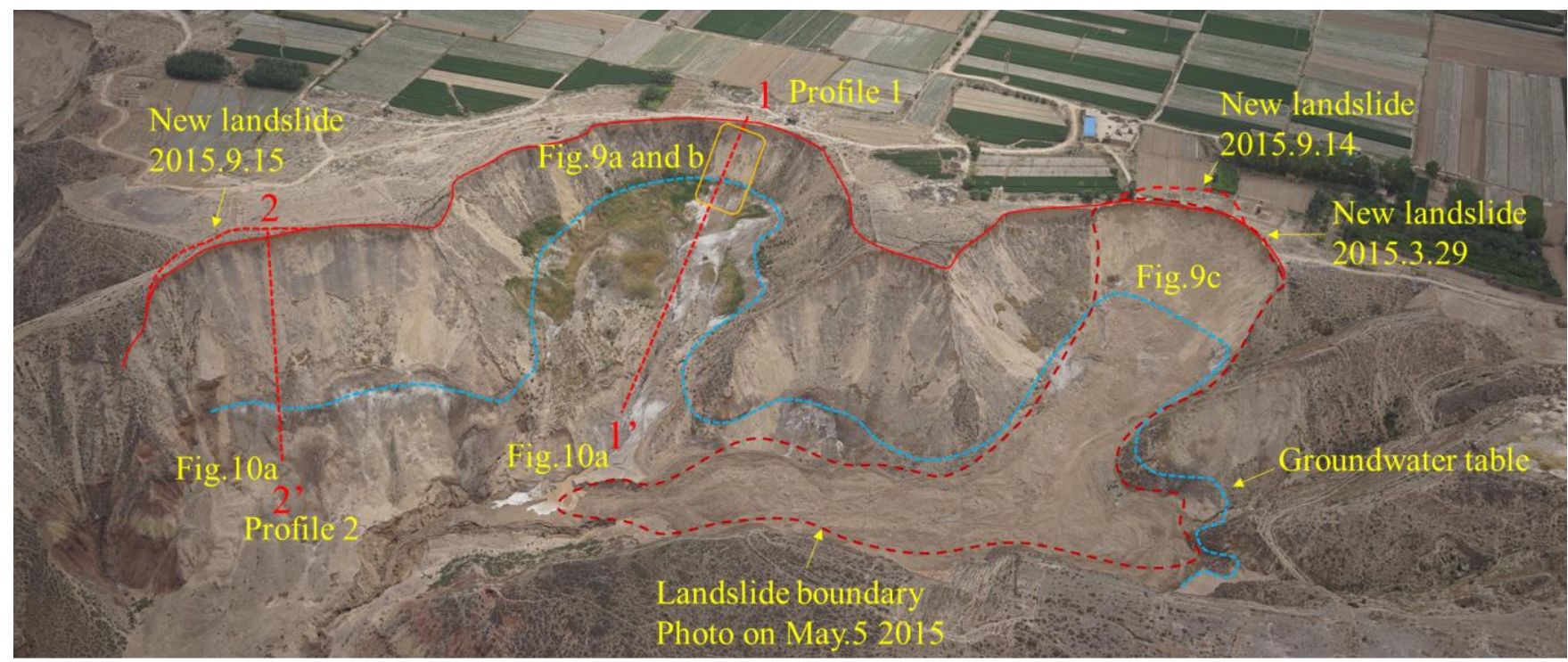

Fig. 7 Landslides in the northern boundary of Heifangtai (for location, see Fig. 1c)

\subsection{Effect of Local underground water level}

\section{1) Model one: rising of local groundwater level due to blockage by landslide deposits}

Heifangtai tableland is a typical loess highland haunted by landslides. Debris would deposit at the toe of pileup soon after loess landslide took place (Figs. 7 and 8). The accumulated debris may block the outlet of internal seepage channels of groundwater at lower places, causing groundwater level keep rising at the edge of the tableland (Xu et al 2012b). Hence, slopes in an appearance of concave is much more prone to sliding. These factors contributed to landslide recurrence and landslide traces identified in Heifangtai (Fig. 4).

At 11:00 on March 29th, 2015, loess landslide, the CJ\#8, occurred in the northern section (6). The landslide resurrected from an old unstable slope and retreated $5.5 \mathrm{~m}$ from the back scarp of the slope. In May 2015, we investigated the landslide by using low-altitude photogrammetry and field measurement to obtain high precision topographic map (Fig. 8). It was evident that groundwater level rising contributed to gradual recession of landslide boundary according to field measured two soil water content profiles and groundwater level position (Fig. 7).

In Fig. 7 and Fig. 9, we used tape to measure the distance from sampling points to the edge of landslide crown at selected two soil water content profiles, and then used the geological profile line to determine the elevation of the location of sampling points. The geological profile line is the same as the water content profile (Figs. 9a and b). The landslide boundary of cross-section 1 retreated more distance along post-sliding landslide than that of cross-section 2 (Fig. 7). Two sites were sampled to measure the average moisture content per $0.5 \mathrm{~m}$ altitude. The results show that the elevation of profile 1 (Fig. 10b) is $19.5 \mathrm{~m}$ higher than profile 2 (Fig. 10c) at the same water content value (Fig. 10a).

By using the Trimble Real-time Kinematic measurement on capillary water zone in loess (Fig. 9c), we obtained the relationship between the water point elevation and distance from the start point. It is found that the two peak values on the curve are $21.4 \mathrm{~m}$ and $18.8 \mathrm{~m}$, which are corresponding to two groundwater outlets blocked (Figs. 7, 8 and 10d). This result is consistent with field water content profile test.

Due to the strong hydrophilic sensitivity, loess is susceptible to moisture with rapid strength loss as long as it was corroded by water. Disturbances of long-term agriculture irrigation on the natural hydrogeological environment at Heifangtai tableland and groundwater level were regularly investigated in recent years. When loess zone got to be saturated and subsoil underneath loess bulk softened, it cultivated a situation favourable for slope failure. The feeble seat earth 


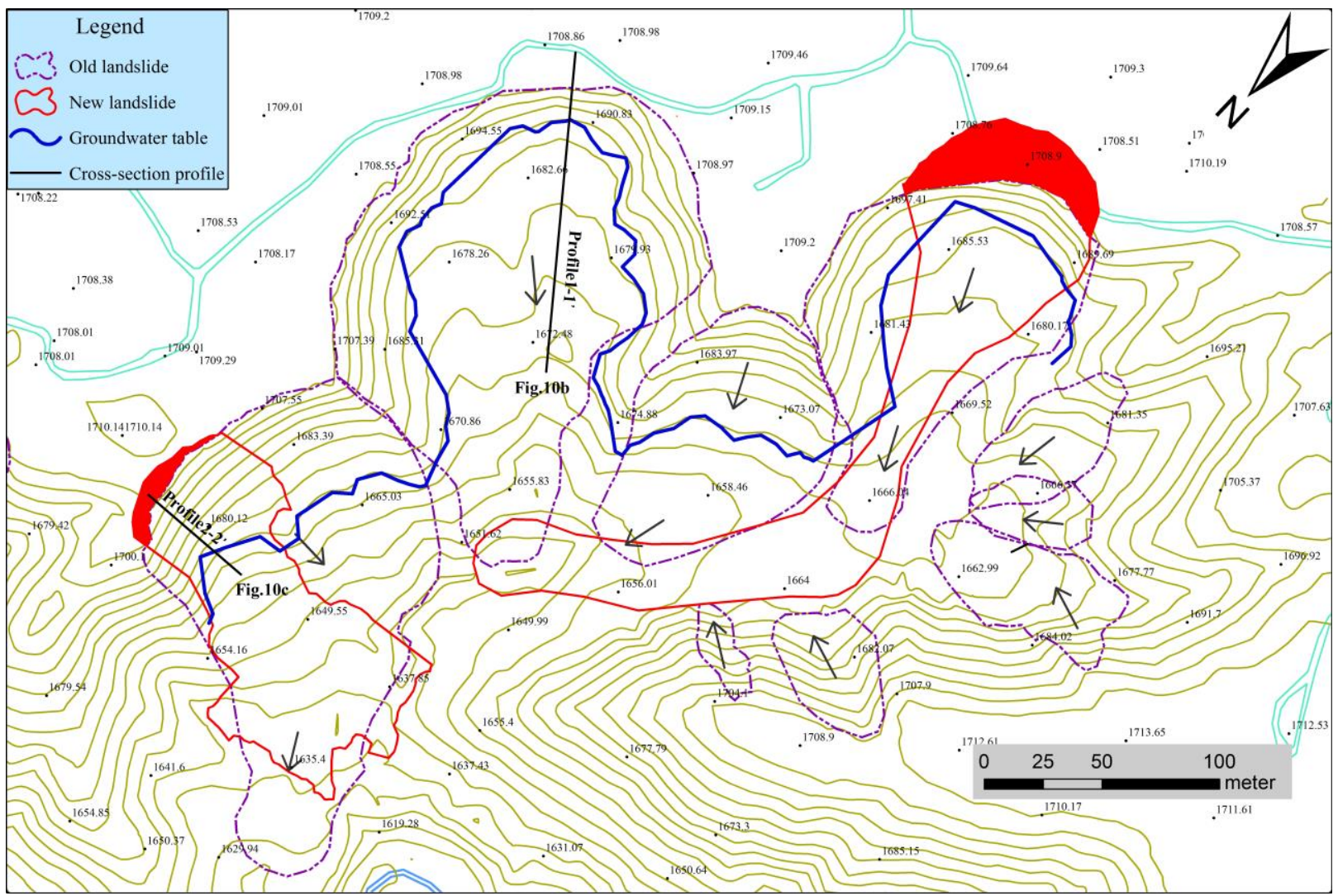

Fig. 8 Topographic map of the study zone in Fig. 9 and the groundwater level (for location, see Fig. 1c).

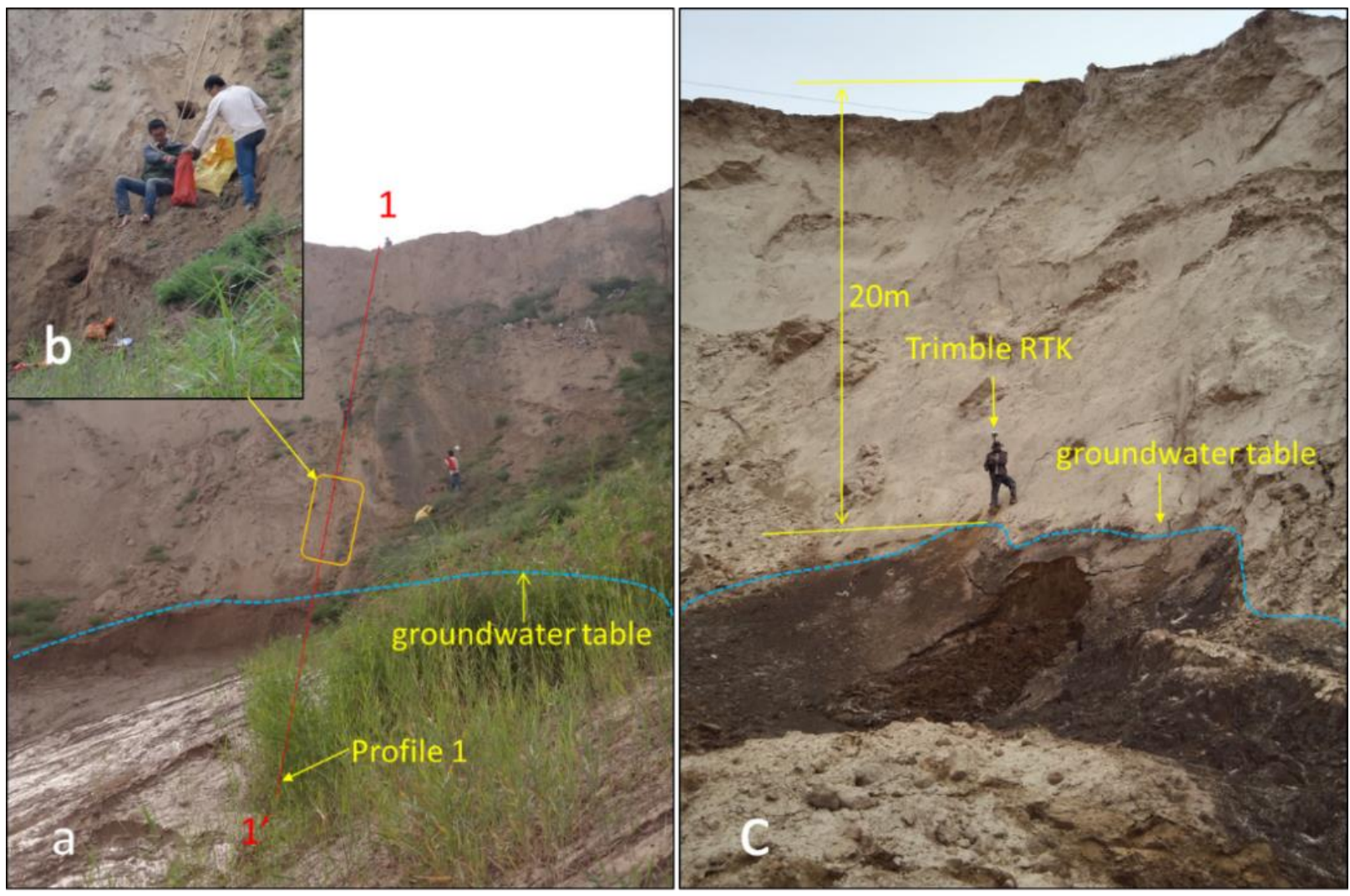

Fig. 9 Field investigation on moisture content and water quality with Real-time Kinematic site (for location, see Figs. $7 \&$ 8) 

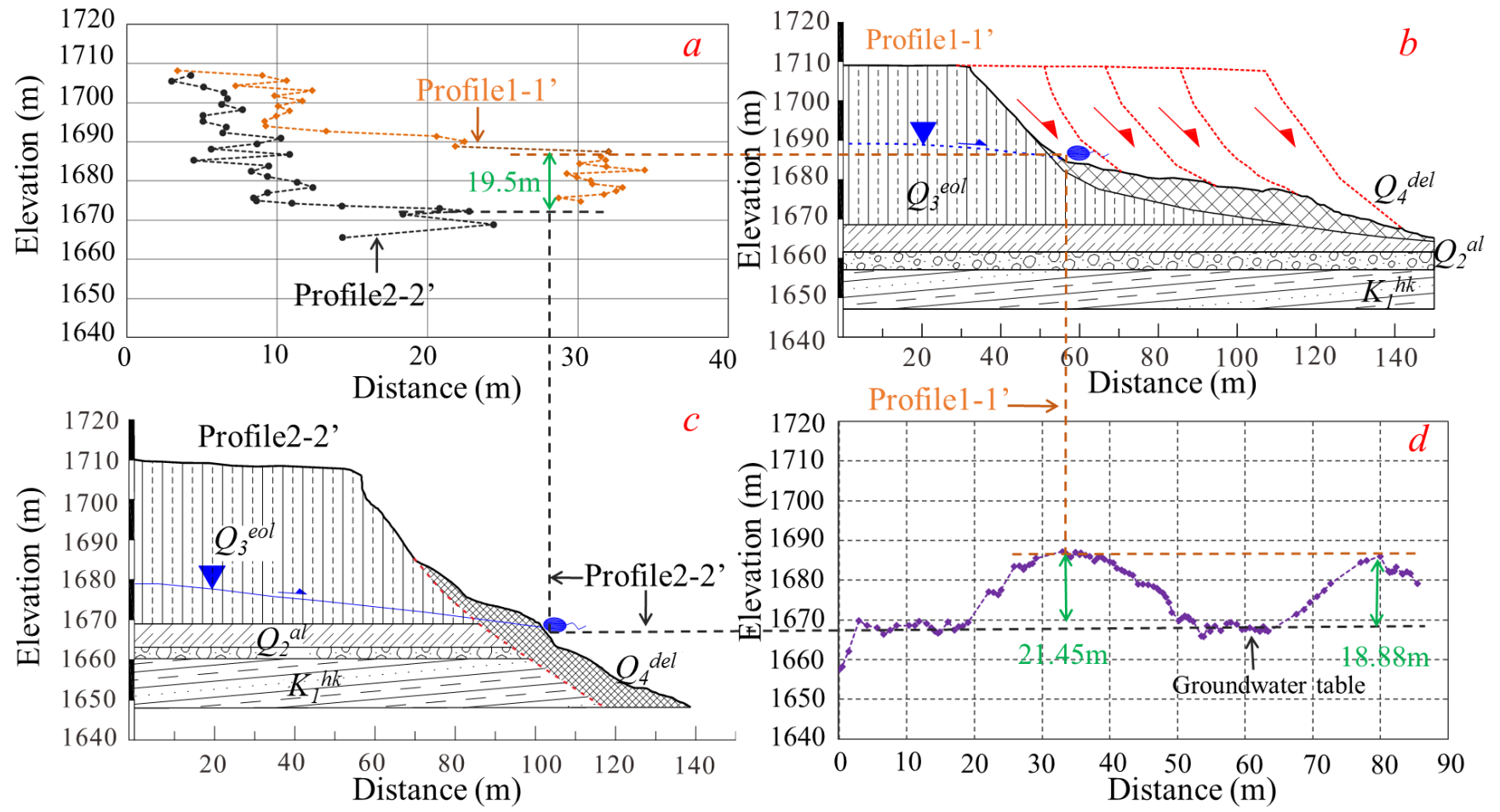

Fig. 10 Groundwater level rising owing to groundwater outlets blocked by landslide deposits. a) The weight moisture content in two profiles; b) The cross-section profile 1; c) The cross-section profile 2; d) underground water table distribution along the edge of the tableland at the Chenjia Gully

was inclined to creep toward open face of slope under the overburden pressure. In the meantime, with non-uniform subsidence and fractures grew in the overlying loess, surface cracks at the edge of tableland extended into the internal slope, generating a potential sliding surface. The pore water pressure will increase with the saturated loess continues to creep. When the pore water pressure exceeds its threshold and the mechanical strength of the loess layer is reduced, liquefaction of upper layer loess will occur causing slip in the end. It is a typical progress before the occurrence of static liquefaction as a type of loess landslides. Accumulated debris blocked transportation openings of groundwater which arrested moisture flow, followed by a rise of underground water table at the edge of the tableland. The rise in groundwater table can lead to soil liquefaction and is responsible for the occurrences of static liquefaction landslide. When the saturated loess layer forms, the soft foundation and the extrusion creep occurs continuously, it is likely to have recurrence of static liquefaction. Loess landslide at Heifangtai is characterized with a step by step back type and static liquefaction. Its disaster mode is shown in Fig. 11.

\section{2) Model two: freeze-thaw-induced rising of local groundwater level}

According to the Yongjing County Land Bureau and relevant statistics (Wu et al 2014, Xu et al 2014), the distribution pattern of groundwater level in this area was non-uniform from 1980 to 2015. As illustrated in Fig. 12, the number of landslides in March during snow melting is quite higher than other months.

Among underlying factors in loess landslide, seasonal freezing and thawing often were ignored (Overduin et al. 2006, Wu et al 2014). With frequent occurrences of landslide during the transitional period between winter and spring, Heifangtai tableland was an ideal place to observe seasonal freeze-thaw action. The freeze-thaw phenomena can be further divided into periodical process with four intervals on a year basis, including a partially frozen period in early winter, a totally frozen period in deep winter, a freezethaw period in spring and a melting period in 


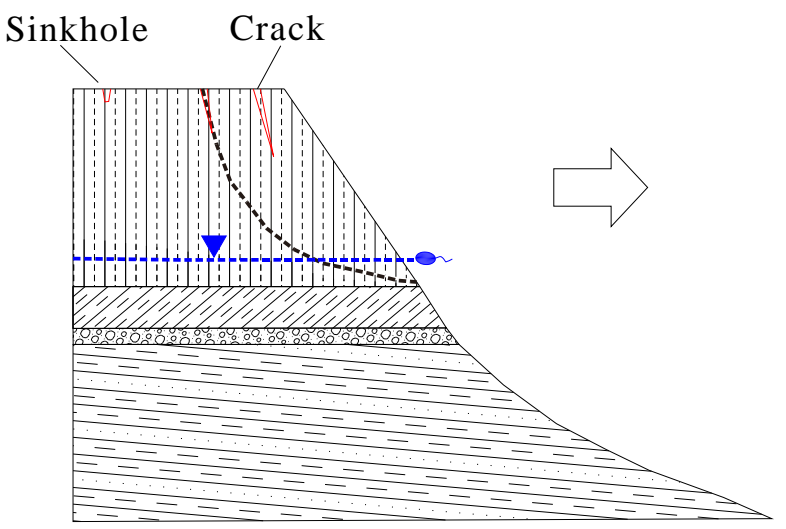

(a)

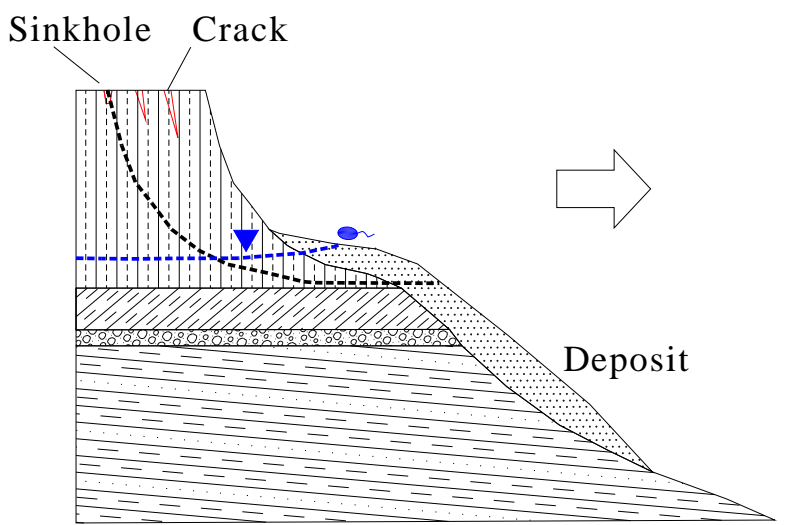

(c)

Loess Alluvial clay
Sinkhole Crack

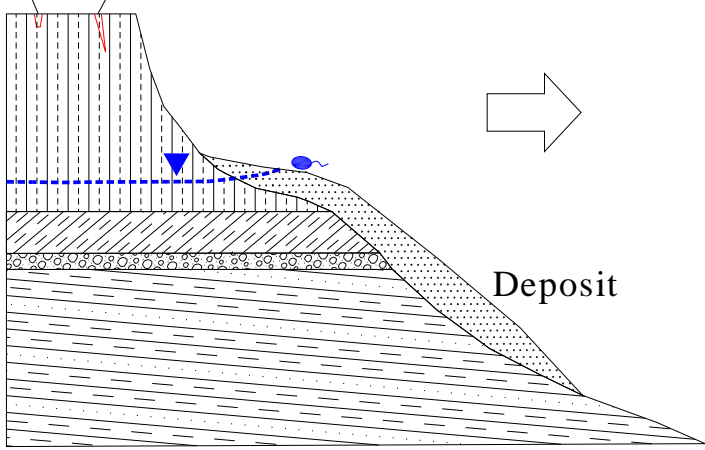

(b)

Crack Post-sliding topographic line

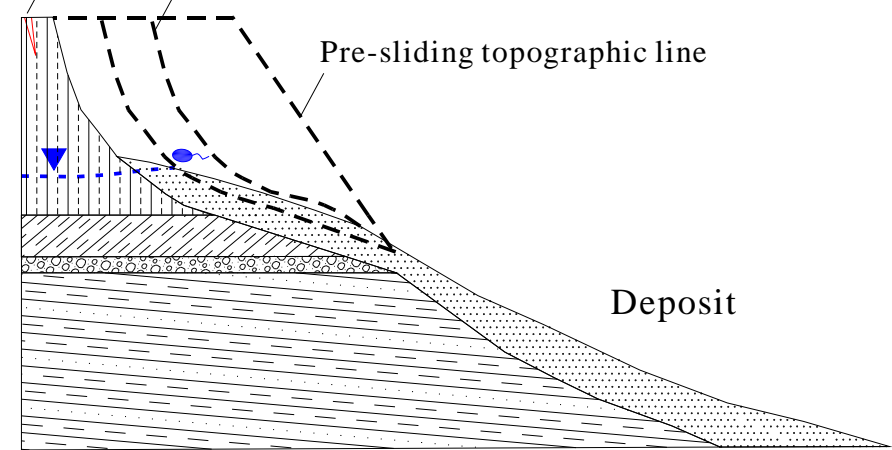

(d)

Mudstone with sandstone partings

Fig. 11 Disaster model of loess static liquefaction. a) The tension cracks grew to the upper part of loess slope; b) Locally underground water level rising because of blockage of underground water outlets by landslide deposits; c) It was easy for presliding landslide to recur static liquefaction of loess landslide again; d) Repeatedly, Heifangtai formed a step by step back type static liquefaction of loess landslide

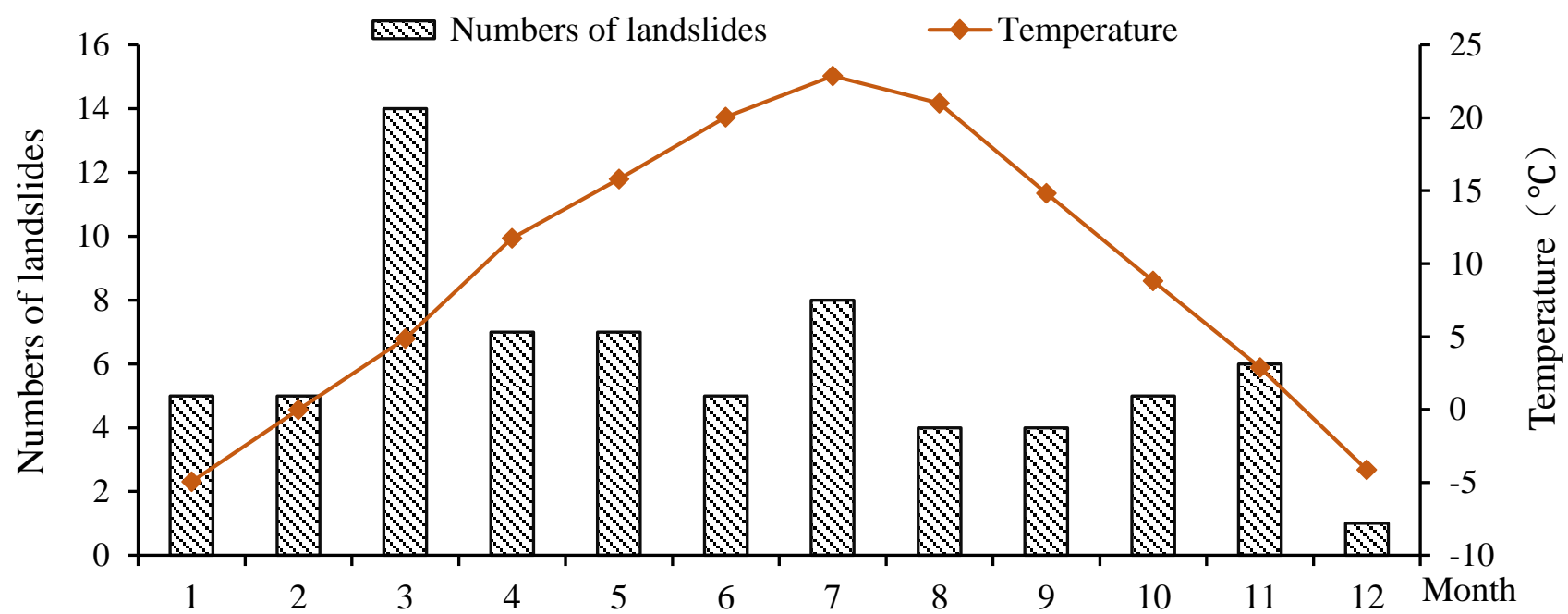

Fig. 12 landslides occurrence demonstrated by month in Heifangtai showing peak number on March 


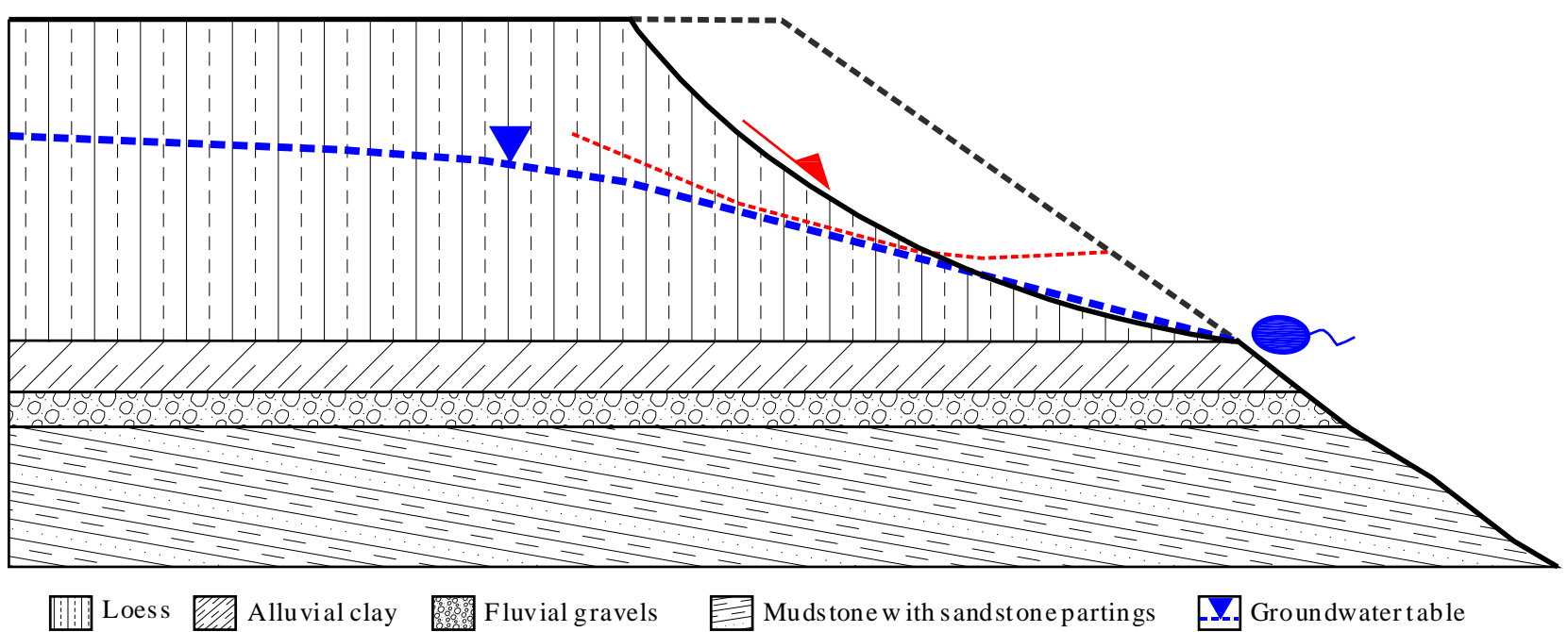

Fig. 13 Freeze-thaw-induced locally rising of underground water level (Zhang et al 2013)

summer. Besides, it contains a daily cycling process in response to daily temperature variation. The failure mechanism of landslide due to freezethawing can be concluded: (1) the physical and mechanical performances of loess are reduced because soil structure is destroyed during the freeze-thawing processes (McKenzie et al 2007). (2) the sliding resistance force is decreased due to sharply increased groundwater level and water pore pressure (Overduin et al 2006, Zhang et al 2013). These analyses demonstrate that the dual functions of the effect of frozen stagnant water and cyclic freeze-thaw were the primitive factors responsible for the frequent occurrences of landslide during spring. Its disaster mode is shown in Fig. 13.

\section{3) Model three: rainfall-induced rising of local groundwater level}

Subjected to gravitational forces and growth of internal stresses due to steep slope, tensile stress rapidly developed at the crest of slope, while shear stress centralized at the foot of the slope (Erginal et al 2008, Wang et al 2014). With rainfall infiltrated at a deeper depth along the weak plane, resulting in weakening of the soil of the inner slope. Vertical joints, which were commonly appear on the Loess Plateau, facilitated the formation of tension cracks in the upper part of cut slopes during excavation (Zhuang and Peng 2014). Under rainfall, the infiltrated moisture could move deeper through weak vertical joints and cracks, responsible for weakening of soil beneath the slope and local groundwater level rising. With initial cracks extended downward and sustained infiltration, it made soil damage in structures and lower loess softened, resulting in a concentration of soil stress in weak zones and forming the saturated zone at the bottom of loess. Then, a shallow collapse landslides would occur at a small scale. Its disaster mode is shown in Fig. 14.

\section{Conclusions}

This paper analyzes the distribution pattern and formation conditions of landslides in Heifangtai region, and ultimately establishes a practical way for early recognition and prediction of future landslides. The results are shown below, (1) The research region on loess landslide could be divided into two first-order sections and six secondary-order sections based on their formation characteristics. Groundwater level rise was the primary factor for frequent occurrences of landslides in the region. It was easy for bedrock landslide to occur in a secondary slope section. Loess landslide usually occurred at sites of transverse and reverse slope sections. (2) Two early recognition criteria were proposed: first, the remaining intact slopes between old landslide sections were the places most likely for new 
landslide to occur; second, the area with rising groundwater level were prone to new landslides. Debris accumulation blocked drainage channels of groundwater, causing underground water table rising at the edge of the tableland. By measuring soil moisture profile and positions of groundwater table, it confirmed that groundwater table has raised by $19.5 \mathrm{~m}$. Both the blockage of underground water outlets by landslide deposits and the freeze in winter rainfall can lead to a rise of local underground water level.

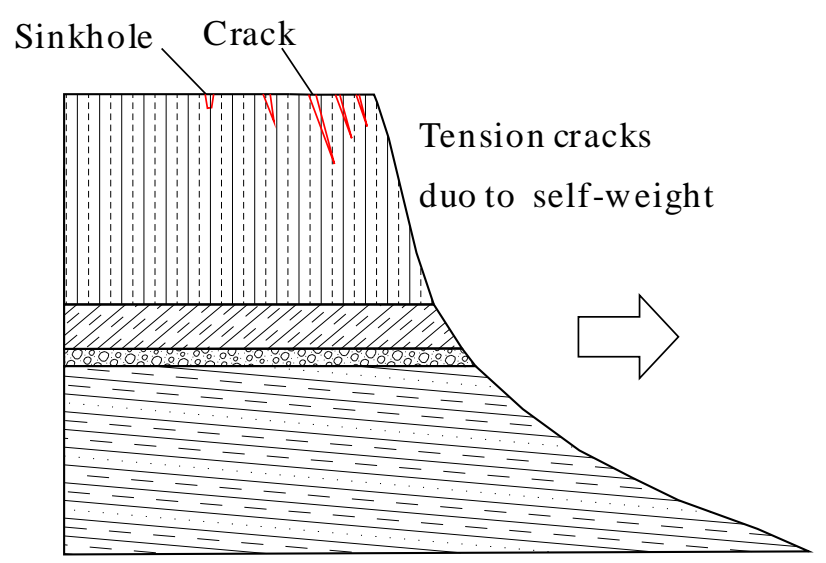

(a)

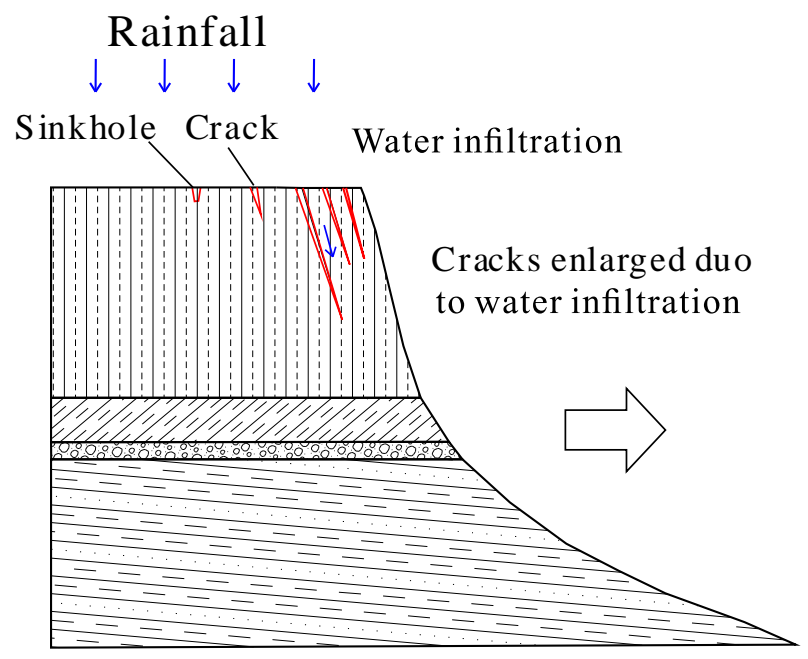

(b)

Long heavy rainfall

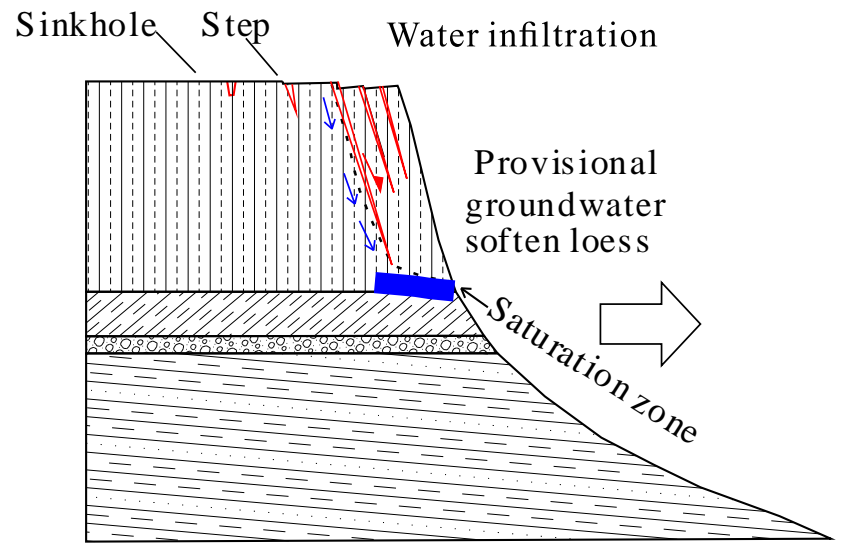

(c)

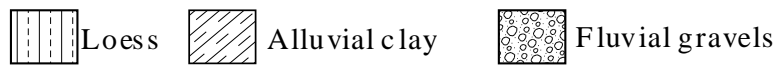

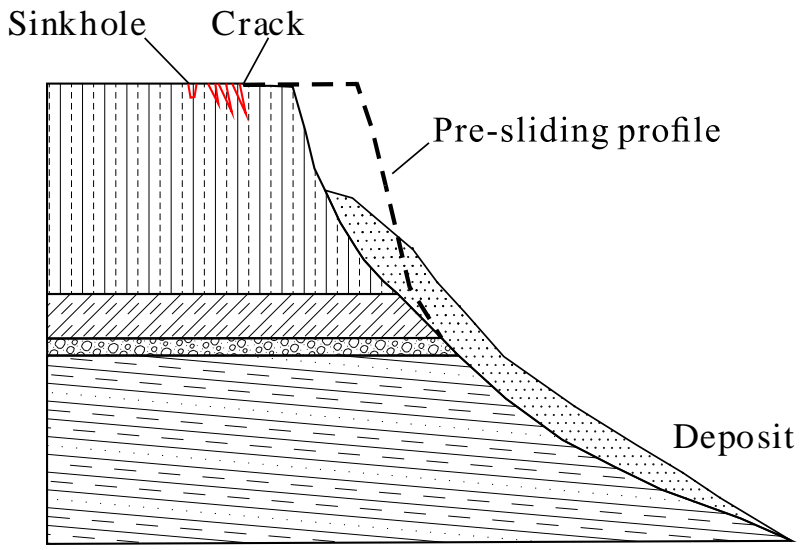

(d)

Mudstone w ith sands tone partings

Fig. 14 Failure mechanisms of rainfall induced loess landslide. a) With gravitational forces, and an increase in internal stresses due to steep open face, tension stresses grew at the crest of the slope while the peaks of shear stress centralized at the foot of the slope; b) surface water infiltrated through vertical joints and cracks; c) As cracks extended downward and laterally after continuous rainfall infiltration, it caused soil failure in structures and softened lower loess; d) a shallow collapse landslides will occur with a small scale

\section{Acknowledgements}

This research was supported by a National Basic Research Program "973" Project from the
Ministry of Science and Technology of the People's Republic of China (2014CB744703), the Funds for Creative Research Groups of China (41521002), as well as the National Science 
Foundation for Distinguished Young Scholars of China (Grant No. 41225011). We thank Maosheng Zhang and Xingmin Meng for the geological materials they provided. The authors thank Guoping $\mathrm{Lu}$ for discussions on earlier versions of the manuscript.

\section{References}

Chen, T., W. Ma, Z.J. Wu and Y.H. Mu, 2014. Characteristics of dynamic response of the active layer beneath embankment in permafrost regions along the Qinghai-Tibet Railroad. Cold Reg Sci Technol, 98: 1 - 7. DOI: 10.1016/j.coldregions.2013.10.004.

Davis, W.M., 1899. The geographical cycle. The Geographical Journal, 14(5): 481 - 504.

Derbyshire, E., 2001. Geological hazards in loess terrain, with particular reference to the loess regions of China. Earth-Sci Rev, 54(1-3): 231260. DOI: $10.1016 / \mathrm{S} 0012-8252(01) 00050-2$.

Derbyshire, E. and T.W. Mellors, 1988. Geological and geotechnical characteristics of some loess and loessic soils from China and Britain A comparison. Eng Geol, 25(2-4): 135 $-175$.

Derbyshire, E., X.M. Meng and T.A. Dijkstra, (eds). 2000. Landslides in the Thick Loess Terrain of North-West China. Wiley, Chichester.

Derbyshire, E., X.M. Meng and R.A. Kemp, 1998. Provenance, transport and characteristics of modern aeolian dust in western Gansu Province, China, and interpretation of the Quaternary loess record. J Arid Environ, 39(3): 497 - 516. DOI: 10.1006/jare.1997.0369.

Derbyshire, E., T. Van Asch, A. Billard and X.M. Meng, 1995. Modelling the erosional susceptibility of landslide catchments in thick loess: Chinese variations on a theme by Jan de Ploey. Catena, 25(1-4): 315 - 331. DOI: 10.1016/0341-8162(95)00015-K.

Derbyshire, E., J.T. Wang, Z.X. Jin, A. Billard, Y. Egels, M. Kasser, D.K.C. Jones, T. Muxart and L. Owen, 1991. Landslides in the Gansu loess of China. Cremlingen, 20: 119 - 145. DOI: 3-923381-29-8/91/5011851.

Erginal, A.E., M. Türkes, T.A. Ertek, A. Baba and C. Bayrakdar, 2008. Geomorphological investigation of the excavation-induced Dündar landslide, Bursa - Turkey. Geografiska Annaler. Series A, Physical Geography, 90(2): 109 - 123.

Gao, W.Y., L. Ming, J.W. Du and Y.L. Wang, 2010. New thought of meteorological forecasting and warning models of geological disasters in Loess Plateau of North Shaanxi. Meteorological and Environmental Research, 8(1): 12 - 16.

Geological Environmental Monitoring Institute of Gansu Province, 2001. Heifangtai landslide disaster survey report, County of Yongjing. Gansu province (in Chinese).

Ishihara, K., S. Okusa, N. Oyagi and A. Ischuk, 1990. Liquefaction-induced flow slide in the collapsible loess deposit in Soviet Tajik. Soils Found, 30(4): 73 - 89. DOI: 10.1016/01489062(91)90223-9.

Jefferson, I.F., D. Evstatiev, D. Karastanev, N.G. Mavlyanova and I.J. Smalley, 2003. Engineering geology of loess and loess-like deposits: a commentary on the Russian literature. Eng Geol, 68(3-4): 333 - 351. DOI: 10.1016/S0013-7952(02)00236-3.

Lin, Z.G. and W.M. Liang, 1982. Engineering properties and zoning of loess and loess-like soils in China. Can Geotech J, 19(1): 76 - 91. DOI: 0008-36741821010076-16.

Liu, T.S. 1985. Loess and the environment. China Ocean Press, Beijing. pp 1 - 481.

McKenzie, J.M., C.I. Vossand and D.I. Siegel, 2007. Groundwater flow with energy transport and water-ice phase change: numerical simulations, benchmarks, and application to freezing in peat bogs. Adv Water Resour, 30(4): $966 \quad-\quad 983 . \quad$ DOI: 10.1016/j.advwatres.2006.08.008.

Meng, X.M., E. Derbyshire and S. Zhang, (eds). 2009. Application of GIS and Remote Sensing to slope instability assessment in loess terrain as a means of documentation, analysis and forecasting. Geological Society Publishing House.

Mentes, G., B. Theilen-Willige, G. Papp, F. Síkhegyi and G. Újvári, 2009. Investigation of the relationship between subsurface structures and mass movements of the high loess bank along the River Danube in Hungary. J Geodyn, 
47(2-3): $130 \quad-\quad 141 . \quad$ DOI: 10.1016/j.jog.2008.07.005.

Muñoz-castelblanco, J.A., J.M. Pereira, P. Delage, and Y.J. Cui, 2012. The water retention properties of a natural unsaturated loess from northern France. Géotechnique, 62(2): 95 106. DOI: 10.1680/geot.9.P.084.

Overduin, P.P., D.L. Kane and W.K.P. van Loon, 2006. Measuring thermal conductivity in freezing and thawing soil using the soil temperature response to heating. Cold Reg Sci Technol, 45(1): $8-22 . \quad$ DOI: 10.1016/j.coldregions.2005.12.003.

Pecsi, M. 1990. Loess is not just the accumulation of dust. Quatern Int, 7/8: 1 - 21.

Peng, J.B., Z.J. Fan, D. Wu, J.Q. Zhuang, F.C. Dai, W.W. Chen and C. Zhao, 2015. Heavy rainfall triggered loess-mudstone landslide and subsequent debris flow in Tianshui, China. Eng Geol, 186: 79 - 90. DOI: 10.1016/j.enggeo.2014.08.015.

Rogers, C.D.F., T.A. Dijkstra and I.J. Smalley, 1994. Hydroconsolidation and subsidence of loess: studies from china, russia, north america and europe: in memory of Jan Sajgalik. Eng Geol, 37(2): 83 - 113. DOI: 10.1016/00137952(94)90045-0.

Sun, J.Z. 1988. Environmental geology in loess areas of China. Environmental Geology and Water Sciences 12(1): 49 - 61. DOI: 10.1007/BF02574827.

Tu, X.B., A.K.L. Kwong, F.C. Dai, L.G. Tham and H. Min, 2009. Field monitoring of rainfall infiltration in a loess slope and analysis of failure mechanism of rainfall-induced landslides. Eng Geol, 105(1-2): 134 - 150. DOI: 10.1016/j.enggeo.2008.11.011.

Wang, J.J., Y. Liang, H.P. Zhang, Y. Wu and X. Lin, 2014. A loess landslide induced by excavation and rainfall. Landslides, 11(1): 141 - 152. DOI: 10.1007/s10346-013-0418-0.

Wasowski, J. and F. Bovenga, 2014. Investigating landslides and unstable slopes with satellite Multi Temporal Interferometry: Current issues and future perspectives. Eng Geol, 174: 103 - $138 . \quad$ DOI: 10.1016/j.enggeo.2014.03.003.

Wen, B. and L. He, 2012. Influence of lixiviation by irrigation water on residual shear strength of weathered red mudstone in Northwest China: Implication for its role in landslides' reactivation. Eng Geol, 151: 56 - 63. DOI: 10.1016/j.enggeo.2012.08.005.

Wu, W.J., X. Su and X.M. Meng, 2014. Characteristics and origin of loess landslides on loess terraces at Heifangtai, Gansu Province, China. Applied Mechanics and Materials, 694: 455 - 461. DOI: 10.4028/www.scientific.net/AMM.694.455

Xiong, L.Y., G.A. Tang, F.Y. Li, B.Y. Yuan and Z.C. Lu, 2014. Modeling the evolution of loess-covered landforms in the Loess Plateau of China using a DEM of underground bedrock surface. Geomorphology, 209: 18 - 26. DOI: 10.1016/j.geomorph.2013.12.009

Xu, L., F.C. Dai, A.K.L. Kwong, H. Min and C. $\mathrm{Xu}, 2009$. Application of IKONOS image in detection of loess landslide at Heifangtai Loess Plateau, China. Journal of Remote Sensing 13(4): 723 - 728.

Xu, L., F.C. Dai, L.G. Tham, Y.F. Zhou and C.X. $\mathrm{Wu}, 2012 \mathrm{a}$. Investigating landslide-related cracks along the edge of two loess platforms in northwest China. Earth Surf Proc Land, 37(10): 1023 - 1033. DOI: 10.1002/esp.3214.

Xu, L., F.C. Dai, X.B. Tu, L.G. Tham, Y.F. Zhou and J. Iqbal, 2014. Landslides in a loess platform, North-West China. Landslides, 11(6): 993 - 1005. DOI: 10.1007/s10346-013-0445-x

Xu, L., X.J. Qiao, C.X. Wu, J. Iqbal and F.C. Dai, $2012 \mathrm{~b}$. Causes of landslide recurrence in a loess platform with respect to hydrological processes. Nat Hazards, 64(2): 1657 - 1670. DOI: 10.1007/s11069-012-0326-y.

Zeng, R.Q., X.M. Meng, J. Wasowski, T. Dijkstra, F. Bovenga, Y.T. Xue and S.Y. Wang, 2014. Ground instability detection using PS-InSAR in Lanzhou, China. Q J Eng Geol Hydroge, 47(4): 307 - 321. DOI: 10.1144/qjegh2014040.

Zhang, D.X. and G.H. Wang, 2007. Study of the 1920 Haiyuan earthquake-induced landslides in loess (China). Eng Geol, 94(1-2): 76 - 88. DOI: 10.1016/j.enggeo.2007.07.007.

Zhang, D.X., G.H. Wang, C.Y. Luo, J. Chen and Y.X. Zhou, 2009. A rapid loess flowslide triggered by irrigation in China. Landslides 6 : 55 - 60. DOI: 10.1007/s10346-008-0135-2 
Zhang, F.Y., W.W. Chen, G. Liu, S.Y. Liang, C. Kang and F.G. He, 2012a. Relationships between landslide types and topographic attributes in a loess catchment, China. J Mt Sci-Engl, 9(6): $742 \quad$ - 751. DOI: 10.1007/s11629-012-2377-7.

Zhang, F.Y., G.H. Wang, T. Kamai, W.W. Chen, D.X. Zhang and J. Yang, 2013a. Undrained shear behavior of loess saturated with different concentrations of sodium chloride solution. Eng Geol, 155: 69 - 79. DOI: 10.1016/j.enggeo.2012.12.018.

Zhang, L.R., Y.C. Shi, G.R. Qiu and K. Liu, 2011. A discussion on dynamic characteristics of undisturbed loess by dynamic triaxial test. Earthquake Research in China, 25(11): 352 357.

Zhang, M.S. and J. Liu, 2010. Controlling factors of loess landslides in western China. Environ. Earth Sci., 59(8): 1671 - 1680. DOI: 10.1007/s12665-009-0149-7.

Zhang, M.S., Y. Dong and P.P. Sun, 2012b. Impact of reservoir impoundment-caused groundwater level changes on regional slope stability: a case study in the Loess Plateau of
Western China. Environ Earth SCI, 66(6): 1715 - 1725. DOI: 10.1007/s12665-012-17286.

Zhang, M.S., X.J. Cheng, Y. Dong, G.Q. Yu, L.F. Zhu and Y. Pei, 2013. The effect of frozen stagnant water and its impact on slope stability: a case study of Heifangtai, Gansu Province. Geological Bulletin of China, 32(06): 852 860.

Zhou, Y.F., L.G. Tham, L. Xu and F.C. Dai, 2013. Site investigation of a loess slope for a field irrigation test. Applied Mechanics and Materials, 275-277: 359 - 362. DOI: 10.4028/www.scientific.net/AMM.275277.359 .

Zhou, Y.F., L.G. Tham, R.W.M. Yan and L. Xu, 2014. The mechanism of soil failures along cracks subjected to water infiltration. Comput Geotech, 55: $330 \quad-341 . \quad$ DOI: 10.1016/j.compgeo.2013.09.009.

Zhuang, J.Q. and J.B. Peng, 2014. A coupled slope cutting - a prolonged rainfall-induced loess landslide: a 17 October 2011 case study. B Eng Geol Environ, 73(4): 997 - 1011. DOI: 10.1007/s10064-014-0645-1. 